\title{
Urban Growth Modelling of Malang City using Artificial Neural Network Based on Multi-temporal Remote Sensing
}

\author{
Agung Bayu Nugroho ${ }^{1}$, Abdul Wahid Hasyim ${ }^{2}$, Fadly Usman ${ }^{2}$ \\ ${ }^{1}$ Master Degree of Civil Engineering Department Interest of Urban and Regional \\ Planning, Universitas Brawijaya, Malang, 65145, Indonesia \\ ${ }^{2}$ Urban and Regional Planning Engineering Department, Universitas Brawijaya, \\ Malang, 65145, Indonesia \\ xceedrift@gmail.com
}

Received 23-08-2018; revised 03-09-2018; accepted 20-09-2018

\begin{abstract}
In this study, the prediction of urban growth was simulated by Artificial Neural Network (ANN) model using MOLUSCE, plugin of QGIS. Objectives of this study is to illustrate the urban growth in Malang City over time span of 24 years and also to predict the future of urban growth using ANN model for the year 2027. Land cover maps were extracted for 2003, 2009 and 2015 via remote sensing images from Landsat ETM+ and OLI, respectively. The overall classification accuracy and kappa coefficient for all classified maps were over $85 \%$ and 0.76 , respectively. According to the simulation result, 1049.58 ha of vegetation and 241.29 ha of bare land in 2015 would experience a transition to built-up areas in 2027. Then, the built-up areas would experience an increase by $11.79 \%$ from 2015 to 2027. In 2027, the built up areas would covered the city by $73.21 \%$ of the city area. There was a trend in increasing of built-up areas during the period 2003 to 2027 . Overall, the result shows that urban growth models by using ANN model can be a considerable option for future changes according to past and current factors.
\end{abstract}

Keywords: urban growth, artificial neural network, land cover, built-up areas, MOLUSCE.

\section{Introduction}

According to the UN's data, $68 \%$ of world's population is estimated to be residing in urban areas in the year 2050 [1]. Furthermore, it has been predicted that by the middle of the 21 century, 7 out of 10 world's population would live in urban areas [2]. Recently, urban growth has been a main issued in land cover changes that have consequences in degradation of vegetation and environment [3]. Urban growth can be monitoring by observing built-up areas in a certain period of time [4]. Observation of land cover changes over time is important as a consideration in urban development planning. [5]. Remote sensing has the ability to get data related to built-up areas or non-built-up areas in an area which is extracted from satellite image data [6].

In this study, change detection would be performed to identify land cover changes in Malang City from 2003 through 2015. Predicting process of land cover map in the year 2027 also would be performed by Artificial Neural Network (ANN) model using MOLUSCE, plugin from QGIS. Then, by comparing two built up areas from 2003 through 2015 and 2027 as the result of the simulation, the urban growth of Malang City can be examined. 


\section{Material and Methods}

\subsection{Study Area}

Malang City is located at East Java in Indonesia. Administratively, the location is surrounded by Malang Regency. Malang City consist of five districts that including Lowokwaru, Kedungkandang, Klojen, Sukun and Blimbing. This city is the second largest city in East Java. This city is also known as the city of education due to many various educational institutions that found in this city. This situation makes this city as a destination for migrants from other regions. Furthermore, the development trend of this city which also leads to industrial and tourism city [7].

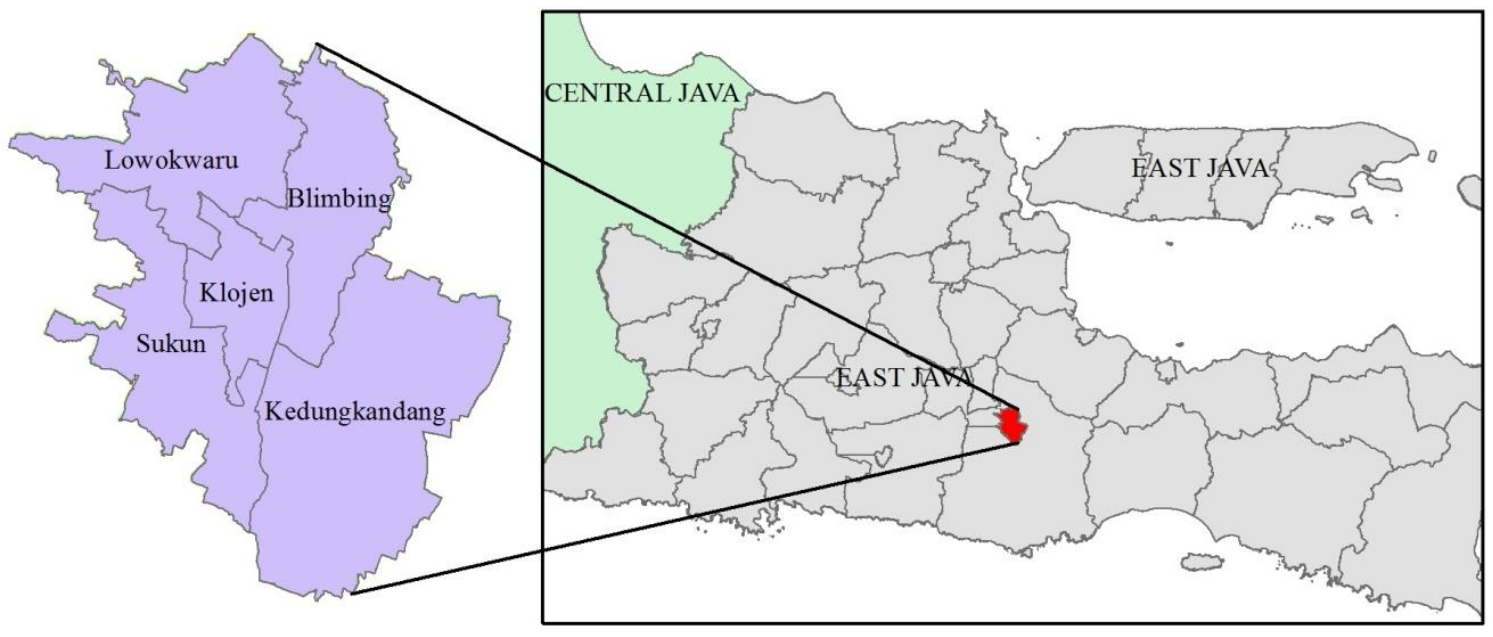

Figure 1. Study Area in Malang City

\subsection{Data collection and preprocessing}

This study used satellite image data that were obtained from Landsat 7 ETM+ and Landsat 8 OLI. According to USGS, these data were included in the "Tier 1" category where appropriate for time-series analysis [8]. To achieve the objectives of this study, satellite image data in 2003, 2009 and 2015 were collected from the USGS website. ASTER DEM was also obtained to get elevation data for slope calculation. Due to scan lines error, the image of the year 2009 (month of July) was corrected by filling gaps with images from another month (month of August).

\subsection{Classification and accuracy assessment}

Supervised classification was performed by using maximum likelihood classification technique to identify land cover classes. Training samples has been selected by observing false-colour tone map. Four land cover categories including bare land, built-up areas, vegetation and water bodies were used in this study. The validation of the land cover maps were calculated by measuring accuracy and kappa coefficient. Google Earth has a main role in calculating of accuracy assessment. Google Earth can be considered as a powerful source that has appropriate accuracy and inexpensive [9]. By using level confidence $95 \%$ and accuracy $90 \%$, as sampling parameters, there were obtained 159 samples. A random set of point was generated in the land cover maps for 2003, 2009 and 2015. Google Earth was used to identifying each point by synchronize it with ERDAS 2014.

\subsection{Change detection in land cover categories}

Change detection was carried out to determine land cover changes from 2003 to 2009 and 2009 to 2015. That method was performed by using MOLUSCE plugin from QGIS. The result of this processing generated raster maps with 16 transition of land cover classes that displayed in post-classification matrix table. In the calculation process, those maps later were converted to vector data. The same method was also used to identify the change detection from 2015 to 2027. 


\subsection{Land cover modelling and validation}

By using MOLUSCE, plugin of QGIS, if the year of 2015 was targeted to be predicted in which to validate the ANN model parameters, land cover maps for year 2003 and 2009 were used. Figure 2 shows ANN diagram model that was used for simulation in this study [10]. Spatial variables maps including distance from main road, distance from river, distance from existing built-up areas in 2009 and slope were also used in the same process.

The validation process was performed to determine the association between 2015's predicted map and 2015's real (actual) map. When the year 2027 was targeted, land cover maps for year 2003 and 2015 were used. In this process, spatial variables to be used were the same as in the validation process except in the distance from existing built up areas in 2009 which replaced with distance from existing built-up areas in 2015. The validation was performed by determining accuracy and kappa coefficient. Once the ANN model parameters were obtained, those were used to predict 2027's land cover map. Simulation process were done separately for each district in Malang City due to gain more simulation result related to urban growth and then recombined them again after the simulation has been done. Urban growth can be analysed by calculating the amount of built-up areas in the city [4].

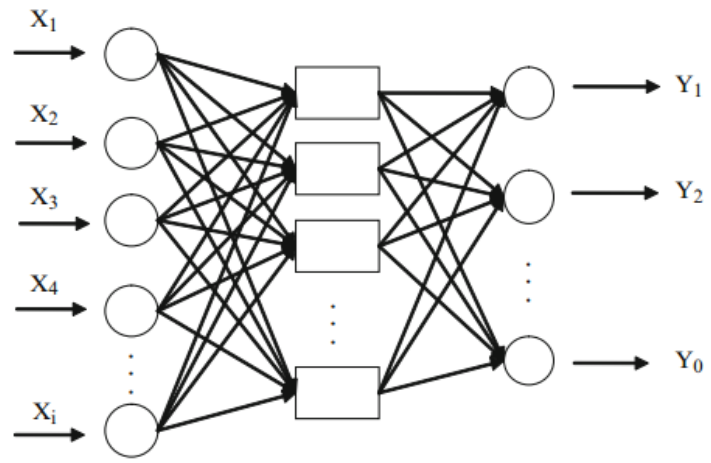

Figure 2. Diagram of Artificial Neural Network Model

Four spatial variables that were used in this study (Table 1) were collected after comparing spatial variables from many literatures $[11,12,13,14,15,16,17]$. Distance from main road and distance from existing built up areas for both year 2009 and 2015 were processed by using Euclidian distance tool in ArcGIS. Distance from river was prepared by using Boolean approach through processing via ArcGIS and IDRISI Selva. Slope was processed by using fuzzy set membership function in IDRISI Selva and ArcGIS. Distance from main road and slope were defined as static factor. Distance from river was also used the same definition due to the existence that almost unchanged in recent years. Distance from existing built-up areas was defined as dynamic factor, which used different data for simulation that targeted for 2015 (validation of ANN model) and 2027.

Table 1. Spatial Variables

\begin{tabular}{ll}
\hline \multicolumn{1}{c}{ Variable Spatial } & \multicolumn{1}{c}{ Description } \\
\hline $\begin{array}{l}\text { Distance from existing } \\
\text { built up areas }\end{array}$ & $\begin{array}{l}\text { Areas that close to existing built-up areas are more appropriate for urban } \\
\text { development than areas far from built-up areas }\end{array}$ \\
\hline $\begin{array}{l}\text { Distance from main } \\
\text { road }\end{array}$ & $\begin{array}{l}\text { Areas that close to main road are more appropriate for built-up areas } \\
\text { than areas far from main road }\end{array}$ \\
\hline Distance from river & $\begin{array}{l}\text { Areas within } 50 \mathrm{~m} \text { of river are considered inappropriate for built-up } \\
\text { areas }\end{array}$ \\
\hline Slope & $\begin{array}{l}\text { Areas that close to zero percent of slope are more appropriate for built- } \\
\text { up areas and areas with slope greater than 15\% are inappropriate }\end{array}$ \\
\hline
\end{tabular}




\section{Result and Discussion}

\subsection{Land Cover Classification, Accuracy Assessment and Change Detection}

Overall accuracy of land cover maps for 2003 (Figure 3), 2009 (Figure 4) and 2015 (Figure 5) were $86 \%, 92 \%$, and $93 \%$, respectively (Table 3 ). Three of them have kappa coefficient above 0.76 that shows good values [18]. According to Table 2 and 3, there were increases by $9.41 \%$ and 10.41 , during the period 2003 to 2009 and from 2009 to 2015, respectively. In another category, vegetation in Malang City decreased by $8.12 \%$ from 2003 to 2009 and $6.91 \%$ from 2009 to 2015 . Bare land also decreased by $1.26 \%$ from 2003 to 2009 and $3.37 \%$ from 2009 to 2015. Another land cover category such as water bodies only get a small percentage decreased compared to vegetation, built-up areas and bare land. Overall, it can be explained that when there was an increase in built-up areas there was a tendency to decrease over bare land and vegetation for the period 2003 to 2009 and 2009 to 2015.

Table 2. Land cover statistic of Malang City, 2003-2009

\begin{tabular}{crrrrrr}
\hline Year & \multicolumn{2}{c}{2003} & \multicolumn{2}{c}{2009} & \multicolumn{2}{c}{ Changes rate } \\
Land cover category & \multicolumn{1}{c}{ ha } & \multicolumn{1}{c}{$\%$} & \multicolumn{1}{c}{ ha } & \multicolumn{1}{c}{$\%$} & \multicolumn{1}{c}{ ha } & \multicolumn{1}{c}{$\%$} \\
\hline Bare land & 778.10 & 7.01 & 637.73 & 5.75 & -140.37 & -1.26 \\
Built-up areas & 4616.31 & 41.60 & 5660.16 & 51.00 & +1043.85 & +9.41 \\
Vegetation & 5640.65 & 50.83 & 4739.44 & 42.71 & -901.21 & -8.12 \\
Water bodies & 62.43 & 0.56 & 60.16 & 0.54 & -2.27 & -0.02 \\
\hline
\end{tabular}

Table 3. Land cover statistic of Malang City, 2009-2015

\begin{tabular}{crrrrrr}
\hline Year & \multicolumn{2}{c}{2009} & \multicolumn{2}{c}{2015} & \multicolumn{2}{c}{ Changes rate } \\
Land cover category & \multicolumn{1}{c}{ ha } & \multicolumn{1}{c}{$\%$} & \multicolumn{1}{c}{ ha } & \multicolumn{1}{c}{$\%$} & \multicolumn{1}{c}{ ha } & \multicolumn{1}{c}{ \% } \\
\hline Bare land & 637.73 & 5.75 & 263.94 & 2.38 & -373.79 & -3.37 \\
Built-up areas & 5660.17 & 51.00 & 6815.15 & 61.41 & 1154.98 & +10.41 \\
Vegetation & 4739.44 & 42.71 & 3972.13 & 35.79 & -767.31 & -6.91 \\
Water bodies & 60.16 & 0.54 & 46.29 & 0.42 & -13.87 & -0.13 \\
\hline
\end{tabular}

Table 4. Post-classification matrix of land cover transition in Malang City from 2003 to 2009 (in hectare)

\begin{tabular}{r|crrrr}
\hline \multicolumn{7}{c}{ 2009 } & & \\
\hline \multirow{4}{*}{2003} & Land cover category & Bare land & Built-up areas & Vegetation & Water bodies \\
\cline { 2 - 6 } & Bare land & 134.42 & 449.07 & 192.99 & 1.62 \\
& Built-up areas & 80.80 & 4333.21 & 195.32 & 6.98 \\
& Vegetation & 418.64 & 867.80 & 4306.44 & 47.78 \\
& Water bodies & 3.87 & 10.09 & 44.70 & 3.78 \\
\hline
\end{tabular}

Table 5. Post-classification matrix of land cover transition in Malang City from 2009 to 2015 (in hectare)

\begin{tabular}{r|crrrr}
\hline \multicolumn{1}{c}{ L } & \multicolumn{6}{c}{2015} & & \\
\cline { 2 - 6 } 2009 & Land cover category & Bare land & Built-up areas & Vegetation & Water bodies \\
\cline { 2 - 6 } & Bare land & 45.40 & 377.26 & 214.26 & 0.81 \\
& Built-up areas & 94.37 & 5315.96 & 227.60 & 22.24 \\
& Vegetation & 122.72 & 1102.28 & 3494.27 & 20.16 \\
& Water Bodies & 1.44 & 19.65 & 35.99 & 3.08 \\
\hline
\end{tabular}




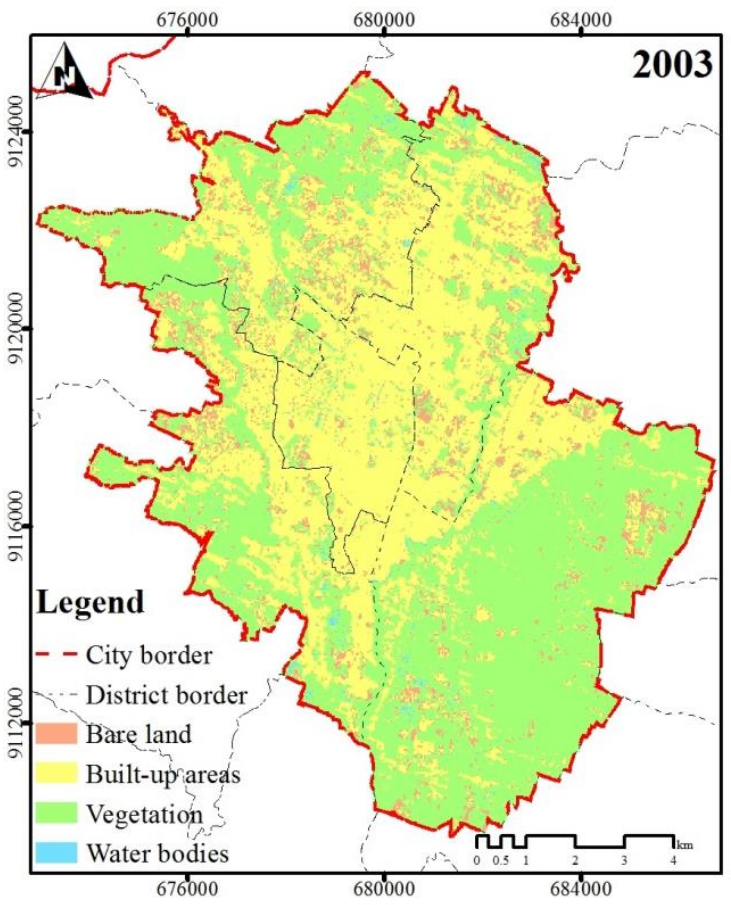

Figure 3. Actual land cover maps for the year 2003.

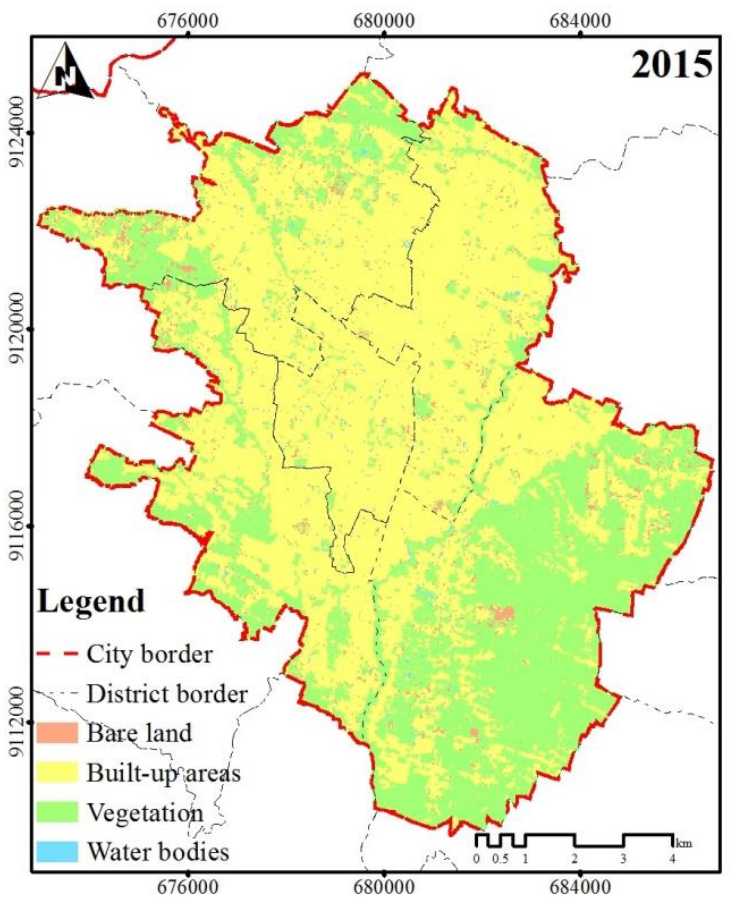

Figure 5. Actual land cover maps for the year 2015

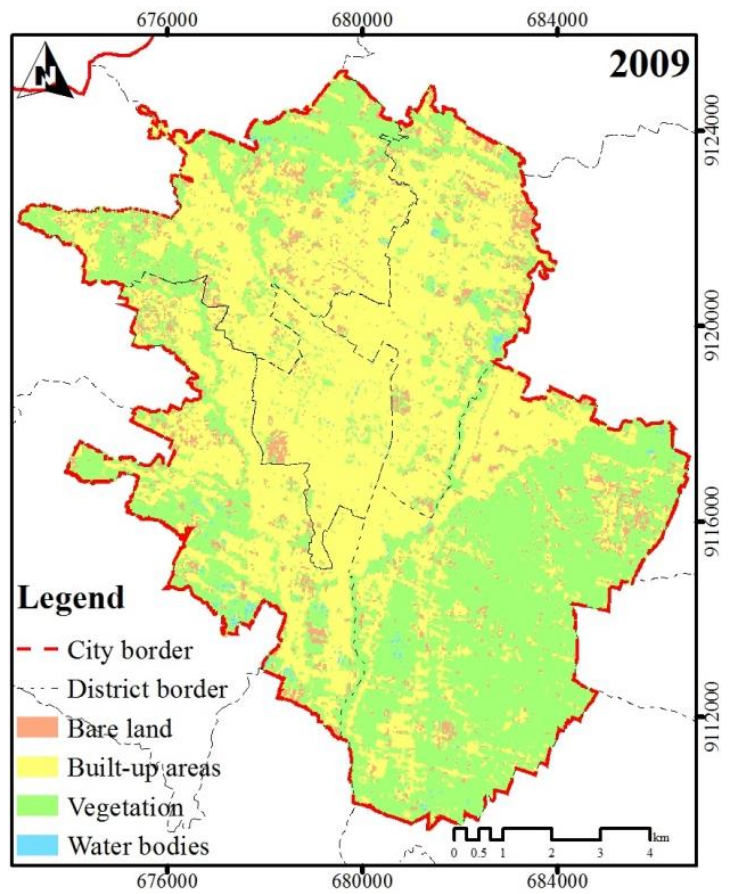

Figure 4. Actual land cover maps for the year 2009

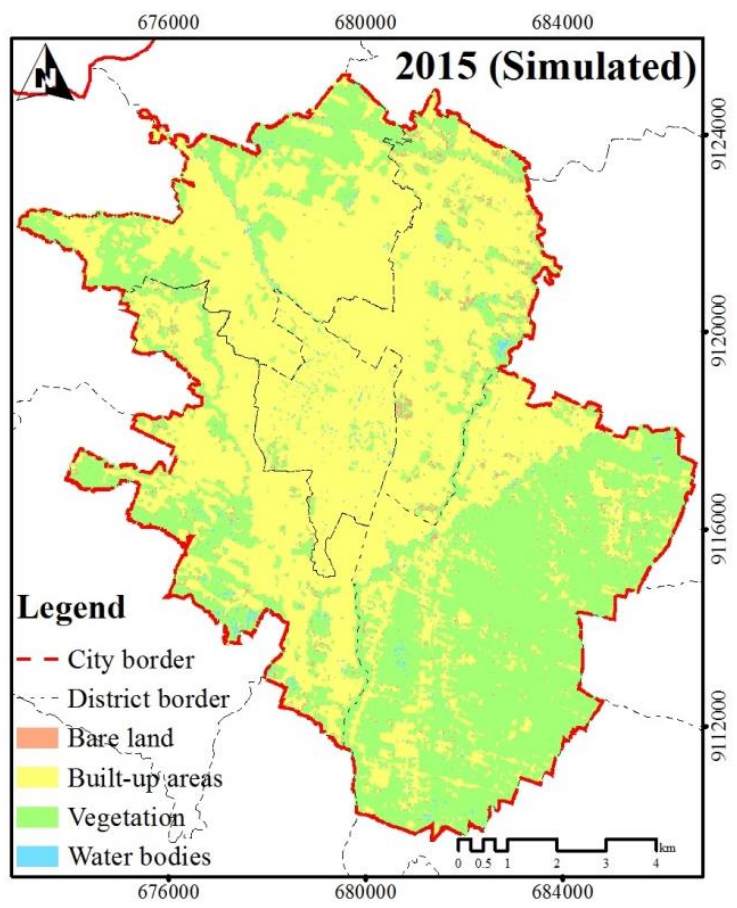

Figure 6. Simulated land cover map for the year 2015

According to Table 4, there were 867.8 ha, 449.07 ha, and 10.09 ha of land cover transition from vegetation to built-up area, bare land to built-up area and water bodies to built-up area for the period 2003 to 2009 , respectively. There were many increasing in the same categories by 1102.28 ha, 377.26 
ha and 19.65 ha for the period 2009 to 2015 , respectively. Therefore, it can be explained that the vegetation provided the greatest contribution in increasing of built-up areas in Malang City for the period 2003 to 2009 and from 2009 to 2015.

\subsection{Land cover modelling and validation}

The validation process was performed for each district by measuring kappa coefficient. ANN model parameters that were used for each district simulation were shown in Table 6. The accuracy for each district in Malang City was above $86 \%$ while the kappa coefficient value for each district was varies. Lowokwaru, Blimbing, and Kedungkandang districts have kappa coefficient value above 0.6 that considered as substantial category. Another two districts, Klojen and Sukun, have kappa coefficient 0.44 and 0.56 that still considered as moderate category. Since, kappa coefficient that has a value below 0.4 considered poor [18], overall ANN model parameters for each district can still be used to predict the future land cover. Figure 6 shows that simulated land cover map of 2015 have been joined from each district as the result of simulation. After validating the model, the land cover map of 2027 was predicted by using 2003 and 2015 land cover map with several spatial variables (distance from main road, distance from river, slope and distance from existing built up areas in 2015). Figure 7 shows the predicted land cover for the year 2027.

Table 6. ANN model parameters for land cover prediction in 2027

\begin{tabular}{ccccccc}
\hline District & $\mathrm{n}$ & $\begin{array}{c}\text { Total } \\
\text { sample }\end{array}$ & $\begin{array}{c}\text { Hidden } \\
\text { layer }\end{array}$ & $\begin{array}{c}\text { Learning } \\
\text { rate }\end{array}$ & Momentum & $\begin{array}{c}\text { Max } \\
\text { Iteration }\end{array}$ \\
\hline Lowokwaru & 1 & 2569 & 32 & 0.01 & 0.05 & 1000 \\
Blimbing & 2 & 2202 & 53 & 0.01 & 0.05 & 1000 \\
Klojen & 1 & 1052 & 32 & 0.01 & 0.1 & 1000 \\
Sukun & 1 & 2450 & 32 & 0.01 & 0.05 & 2000 \\
Kedungkandang & 1 & 4560 & 32 & 0.01 & 0.1 & 2000 \\
\hline
\end{tabular}

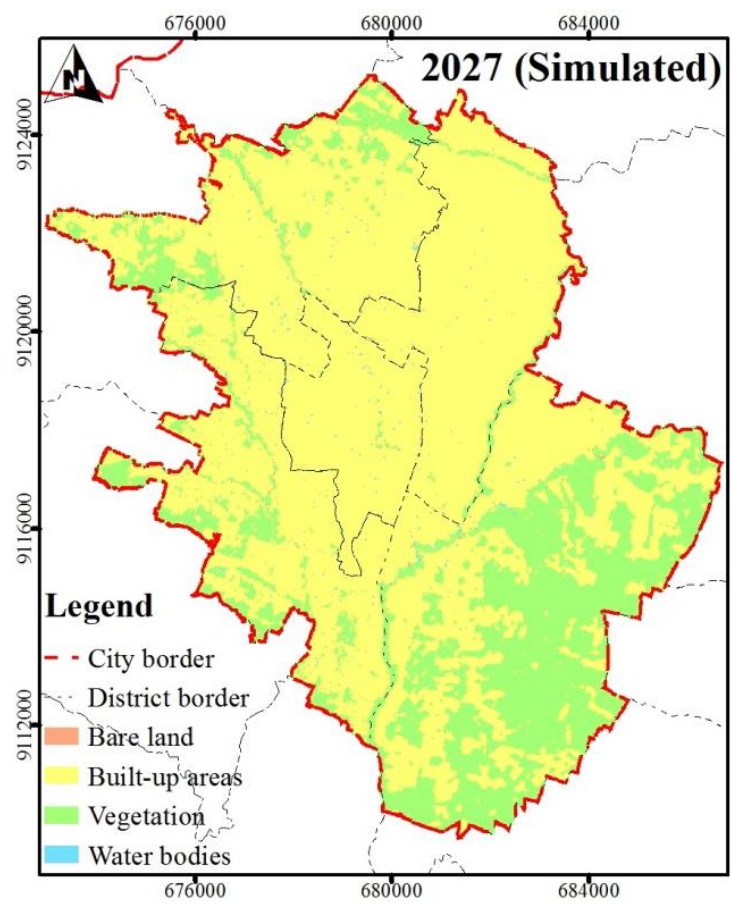

Figure 7. Simulated land cover map for the year 2027

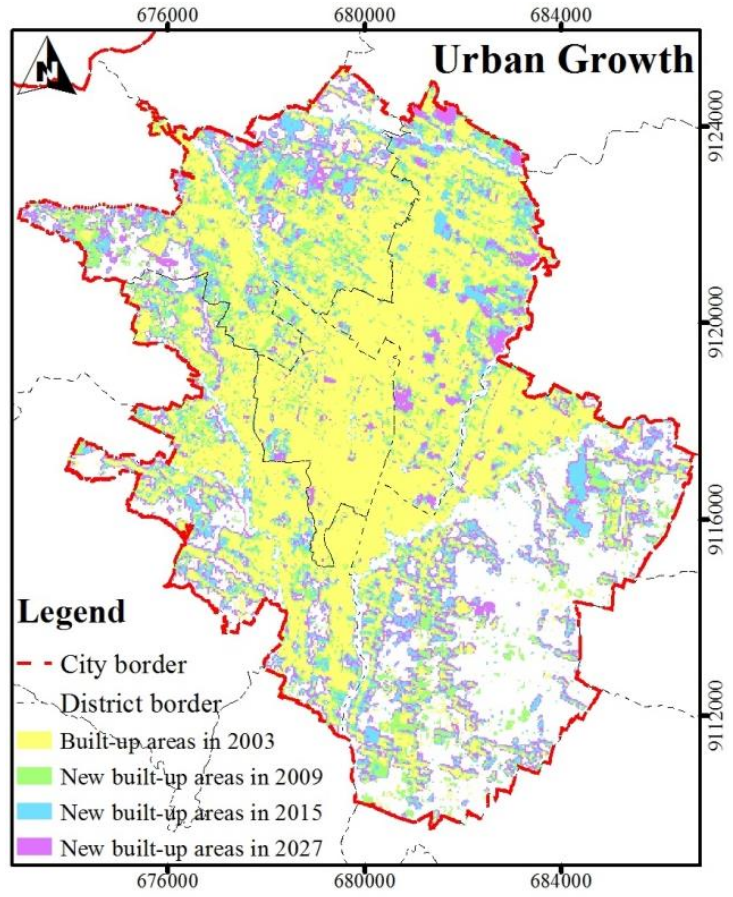

Figure 8. Urban growth in Malang City from 2003 to 2027 
Table 7. Land cover statistic of Malang City, 2015-2027

\begin{tabular}{crrrrrr}
\hline Year & \multicolumn{2}{c}{2015} & \multicolumn{2}{c}{2027} & \multicolumn{2}{c}{ Change rate } \\
Land cover category & \multicolumn{1}{c}{ ha } & \multicolumn{1}{c}{$\%$} & \multicolumn{1}{c}{ ha } & \multicolumn{1}{c}{$\%$} & \multicolumn{1}{c}{ ha } & \multicolumn{1}{c}{$\%$} \\
\hline Bare land & 263.94 & 2.38 & 18.69 & 0.17 & -245.25 & -2.21 \\
Built-up areas & 6815.15 & 61.41 & 8124.09 & 73.21 & 1308.95 & +11.79 \\
Vegetation & 3972.13 & 35.79 & 2928.40 & 26.39 & -1043.73 & -9.41 \\
Water bodies & 46.29 & 0.42 & 26.32 & 0.24 & -19.97 & -0.18 \\
\hline
\end{tabular}

Table 8. Post-classification matrix of land cover transition in Malang City from 2015 to 2027 (in hectare)

\begin{tabular}{c|ccccc}
\hline \multicolumn{5}{c}{} & \multicolumn{5}{c}{$\mathbf{2 0 2 7}$} \\
\hline \multirow{3}{*}{2015} & Land cover category & Bare land & Built-up areas & Vegetation & Water bodies \\
\cline { 2 - 6 } & Bare land & 18.33 & 241.29 & 4.32 & 0.00 \\
& Built-up areas & 0.00 & 6815.06 & 0.09 & 0.00 \\
& Vegetation & 0.36 & 1049.58 & 2922.19 & 0.00 \\
& Water bodies & 0.00 & 18.17 & 1.80 & 26.32 \\
\hline
\end{tabular}

According to Table 7, built-up areas increased by $11.79 \%$ representing 1308.95 ha in the year 2027 . Another three of land cover categories, bare land, vegetation and water bodies decreased by $2.21 \%$, 9.41\% and $0.18 \%$, representing 248.04 ha, 1021 ha and 21.95 ha, respectively. Based on Table 7, there was an increase in built-up areas from 6815.15 ha to 8124.09 ha during the period 2015 to 2027 . There were 1049.58 ha of vegetation that have transformed into built-up areas from 2015 to 2027 (Table 8). There was a degradation of continuous vegetation loss with increasing rates $8.12 \%, 6.91 \%, 9.41 \%$, between 2003-2009, 2009-2015 and 2015-2027, respectively. According to Table 4, 5 and 8, a lot of vegetation experiences a transition into built-up areas rather than into other land cover categories such as bare land and water bodies.

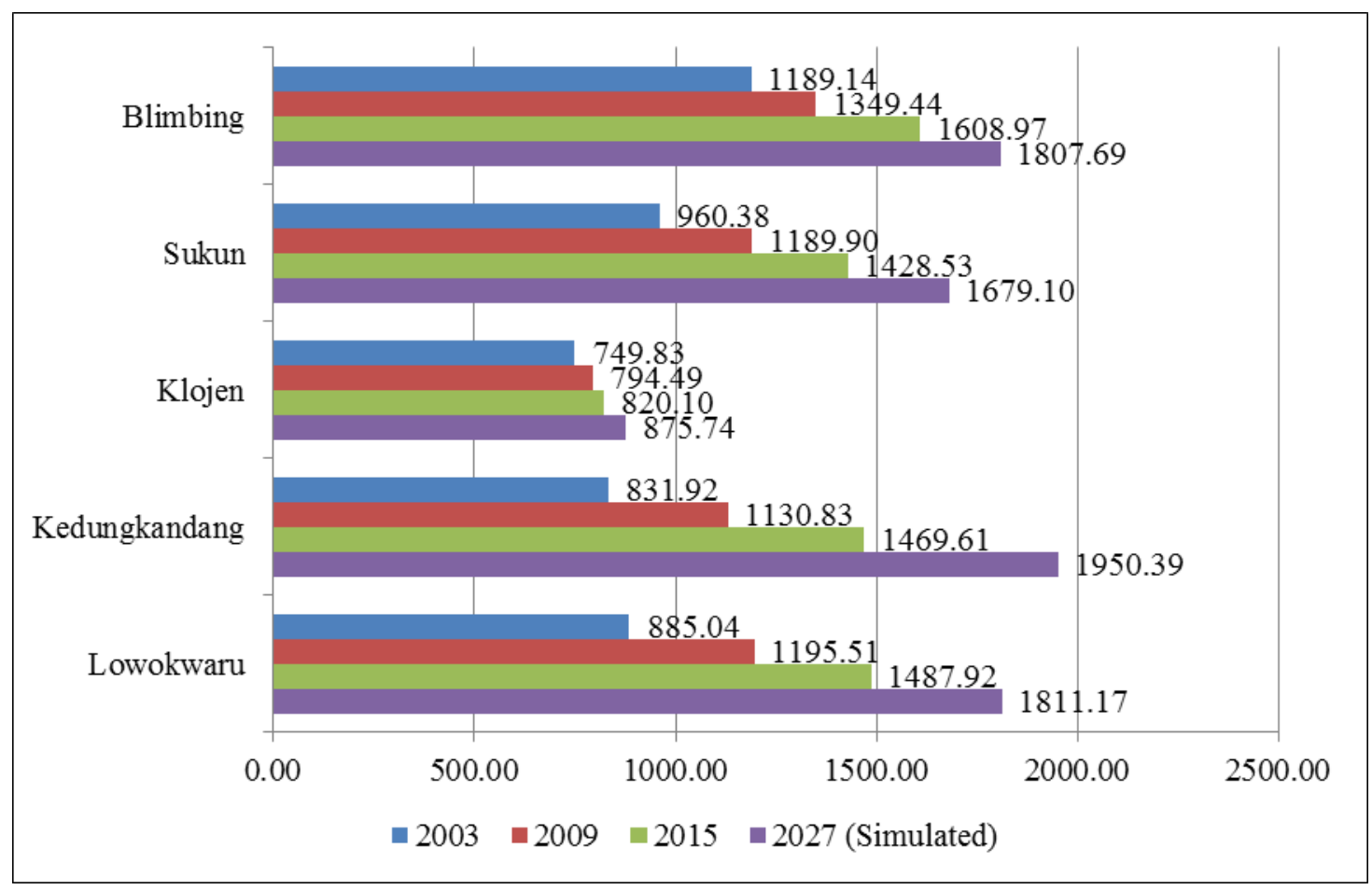

Figure 9. Built-up areas change in each district of Malang City from 2003 to 2027 (in hectare) 


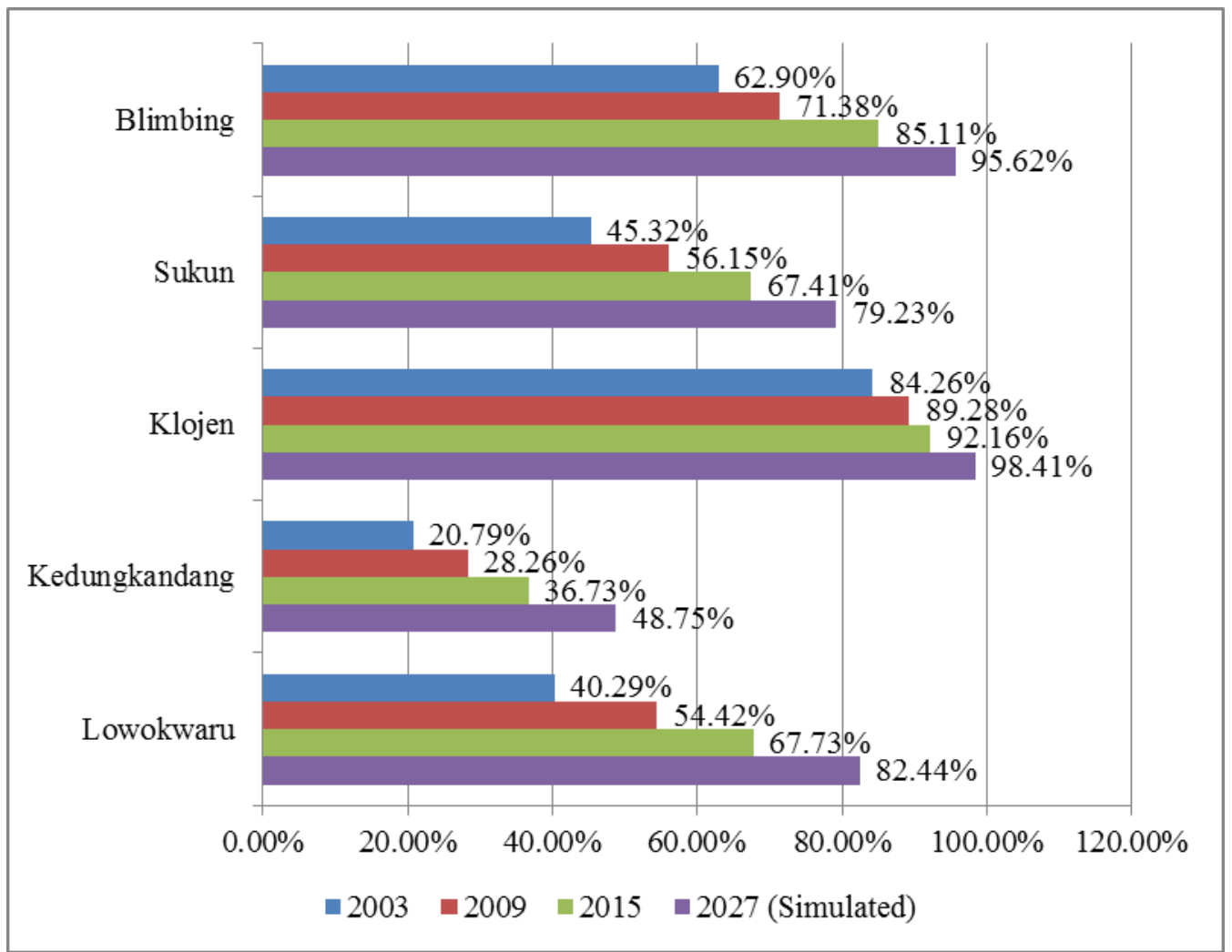

Figure 10. Percentage of built-up areas in each district of Malang City from 2003 to 2027

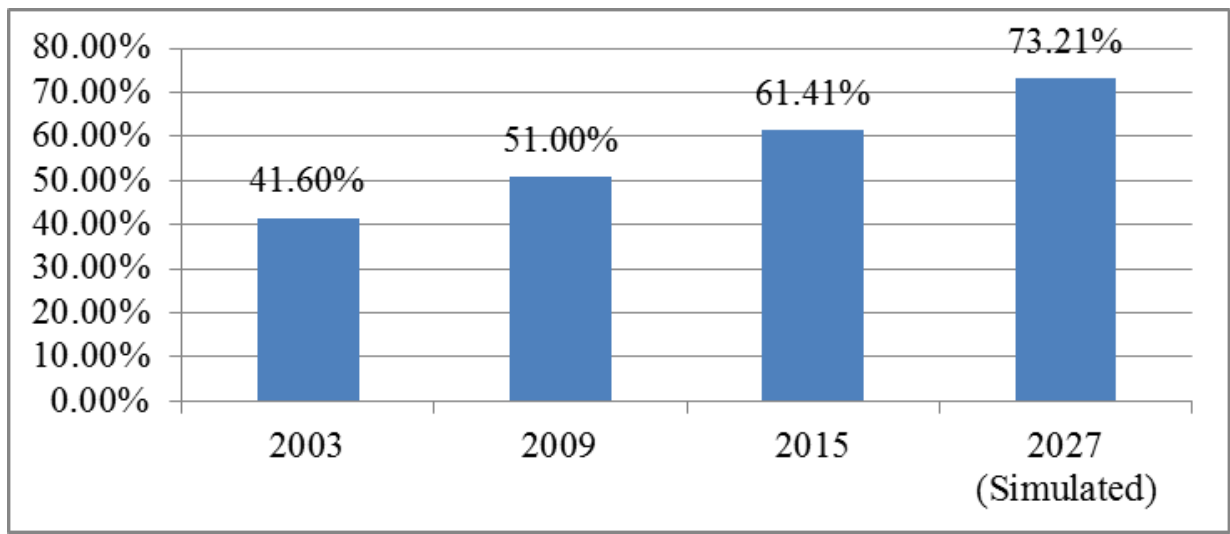

Figure 11. Percentage of built-up areas in Malang City from 2003 to 2027

According to Figure 8, Figure 9 and Figure 10, there was a trend of increasing built-up areas in each district in Malang City from 2003 to 2027. Kedungkandang was a district with the biggest built-up areas despite the percentage was the lowest from 2003 to 2027. On the contrary, Klojen was a district with biggest percentage of built-up areas though the size was the lowest. Blimbing was the second largest district in the largest percentage of built areas in the year 2027. Based on the simulation result, Blimbing and Klojen almost covered their areas by built-up areas, representing $95.62 \%$ and $98.41 \%$ of their total areas in 2027, respectively. The district that has largest vegetation areas was Kedungkandang. The district has 2038.90 ha of vegetation areas. Figure 11 shows that the built-up areas would covered $73.21 \%$ of Malang City areas in the year 2027 after increasing 31.61\% from the year 2003 .

\section{Conclusions}


This study shows that simulation approaches by using ANN model can be a considerable option to predict land cover future changes and the direction of spatial distribution in Malang City. Three Landsat data that were obtained in 2003, 2009 and 2015 were classified by using supervised classification. Land cover change detection was determined by using post-classification matrix. In general, based on the data on land cover changes, it was explained that vegetation contributed greatly in increasing of built up areas in Malang City from 2003 to 2027. There was a trend of increasing built-up areas during the period 2003 to 2027.

The predicted land cover map in 2027 by ANN model indicated that the built up areas would continue increasing up to $73.21 \%$ of the city areas. However, if the urban growth data was compared in the 12 year intervals, in the period 2003 to 2015 and 2015 to 2027, the built-up areas would experience an increase by $19.81 \%$ and $11.79 \%$, respectively. There was a decrease in the percentage of built-up areas by $8.02 \%$ in the last period compared with the first period. Blimbing and Klojen were two districts that would almost covered their areas with built-up areas in 2027 based on simulation result. Kedungkandang would have the lowest of built-up areas by $48.75 \%$ in 2027 based on the simulation result. Overall, the results of this study can be used as an option to be considered by city planners, government and all decision makers that involved in the decision making process for preparation of city spatial planning and environmental sustainability.

\section{References}

[1] UN, 2018. World Urbanization Prospects : The 2018 Revision. https://esa.un.org/unpd/wup/publications/Files/WUP2018-KeyFacts.pdf

[2] UN-Habitat. 2013. State of World's Cities 2012/2013. Prosperity of Cities. (Earthscan : London).

[3] Xian, G. Z. 2016. Remote Sensing Application for the Urban Environment (CRC Press: New York)

[4] Bhatta, B. 2012 Urban Growth Analysis and Remote Sensing : Case of Kolkata, India 1980-2010 (Springer : New York)

[5] Lavender S. and Lavender A. 2016. Practical Handbook of Remote Sensing (CRC Press : New York)

[6] Giri C.P.,2012. Remote Sensing of Land Use and Land Cover : Principles and Application (CRC : Press : New York)

[7] Malik, N. 2016. Dinamika Pasar Tenaga Kerja Indonesia (UMM Press : Malang)

[8] USGS. 2016. Landsat Collection - 2016. https://landsat.usgs.gov/sites/default/files/documents/ Special_Iss3_2016.pdf

[9] Tilahun A. and Teferie B. 2016. Accuracy Assessment of Land Use Land Cover Classification using Google Earth. American Journal of Environmental Protection 2015; 4(4): p 193-198

[10] Livingstone D.J. 2008. Artificial Neural Network Method and Application (Humana Press)

[11] Megahed Y., Cabral P., Silva J., Caetano M. 2015. Land Cover Mapping Analysis and Urban Growth Modelling Using Remote Sensing Techniques in Greater Cairo Region-Egypt. SPRS Int. J. Geo-Inf. 2015, 4, p 1750-1769

[12] Araya H. Y. and Cabral P.. 2010. Analysis and Modeling of Urban Land Cover Change in Setúbal and Sesimbra, Portugal. Remote Sens. 2010, 2, p 1549-1563

[13] Vaz E. and Arsanjani J.J.. 2015. Predicting Urban Growth of the Greater Toronto Area Coupling a Markov Cellular Automata with Document Meta-Analysis. Journal of Environmental Informatics 2015

[14] Ozturk D. 2015. Urban Growth Simulation of Atakum (Samsun, Turkey) Using Cellular Automata-Markov Chain and Multi-Layer Perceptron-Markov Chain Models. Remote Sens. 2015, 7, p.5918-5950

[15] Triantakonstantis D. and Stathakis D. 2015. Urban Growth Prediction in Athens, Greece, Using Artificial Neural Networks. International Journal of Architectural and Environmental Engineering Vol:9, No:3, 2015

[16] Moghaddam K.H. and Samadzadegan F. 2009. Urban simulation Using Neural Networks and 
Cellular Automata for Land Use Planning. REAL CORP 2009: CITIES 3.0 - Smart, Sustainable, Integrative

[17] Rahman M.T.U., Tabassum F., Rasheduzzaman M., Saba H., Sarkar K.. Derfous J., Uddin S.Z., Islam A.Z.M.Z. 2017. Temporal dynamics of land use/land cover change and its prediction using CA-ANN model for southwestern coastal Bangladesh. Environ Monit Assess (2017) 189:565

[18] Hay S.I., Randolph S.E., Rogers D.J. 2000. Remote Sensing and Geographical Information Systems in Epidemiology (Academic Press: New York) 